\title{
An Abode of Islam under a Hindu King: \\ Circuitous Imagination of Kingdoms Among Muslims of Sixteenth-Century Malabar
}

\author{
Mahmood Kooria
}

To cite this article: Kooria, Mahmood. "An Abode of Islam Under a Hindu King: Circuitous Imagination of Kingdoms among Muslims of Sixteenth-Century Malabar." Journal of Indian Ocean World Studies, 1 (2017), pp. 89-109.

More information about the Journal of Indian Ocean World Studies can be found at: jiows.mcgill.ca

(c) Mahmood Kooria. This is an Open Access article distributed under the terms of the Creative Commons License CC BY NC SA, which permits users to share, use, and remix the material provide they give proper attribution, the use is non-commercial, and any remixes/transformations of the work are shared under the same license as the original. 


\title{
An Abode of Islam under a Hindu King: Circuitous Imagination of Kingdoms among Muslims of Sixteenth-Century Malabar
}

\author{
Mahmood Kooria* \\ Leiden University, Netherlands
}

\begin{abstract}
When Vasco da Gama asked the Zamorin (ruler) of Calicut to expel from his domains all Muslims hailing from Cairo and the Red Sea, the Zamorin rejected it, saying that they were living in his kingdom "as natives, not foreigners." This was a marker of reciprocal understanding between Muslims and Zamorins. When war broke out with the Portuguese, Muslim intellectuals in the region wrote treatises and delivered sermons in order to mobilize their community in support of the Zamorins. Such treatises, which had very strong jihadi content, are very interesting to analyze. Most authors of these works extensively invoked classical Islamic texts, such as the Quran and Hadiths, and the theocratic-geographical units of dār al-Islam ("abode of Islam") in contrast to the dār al-harb ("abode of war") in order to incite jihad against the Portuguese. Some of them highlighted the Hindu Zamorin as possessing the requisite moral, cultural and political qualities to rule a region, as opposed to corrupt Muslim kings who forged alliances with the "cross-worshipping" Portuguese. This article explores, within the context of "jihad" in Hindu-ruled territories, the background to these writings and the varied socio-cultural activities and preferences of their Muslim authors.
\end{abstract}

\section{INTRODUCTION}

Affiliation with a distant place is significant for itinerant individuals and diasporiccosmopolitan societies, whether medieval, modern or contemporary. This affiliation was not meant to indicate disassociation with other places to which they travelled or where they resided, nor to demonstrate their exclusive loyalty to a distant ruler. Rather, it was primarily a marker of several socio-cultural attachments that needed to be expressed and identified in a pluralistic atmosphere. Philip D. Curtin has argued that such attachments played roles in the relationships between different nodal points within and beyond trade diasporas. This was certainly the case for itinerant communities of the Indian Ocean World (IOW) when they settled in new locations. In this article, I explore the social, political and religious imaginations of territory as described by 
the Muslim intelligentsia of sixteenth-century Malabar, on the south-western coast of the Indian subcontinent. As the burgeoning field of IOW studies motivates us to think beyond conventional area studies, I will here explain how a religious-scholarly community from the Indian Ocean littoral imagined "areas" without borders. Utilizing a number of published and unpublished Arabic, Malayalam and European sources, I examine the micro-history of a small group in a small place who nevertheless possessed strong mercantile, cultural and political connections with the wider IOW.

\section{Muslims of Malabar and the Question of Loyalty}

In the sixteenth century, Muslims comprised a minority of the population of the Malabar Coast which was divided into many minor kingdoms. These included the Zamorin kingdom with its capital in Calicut, the Kōlattiri realm centred at Kōlattunātu, the 'Âlī Rajas at Cannanore, and the Cochin Rajas at Perumpatappunātu/Cochin. Islam probably arrived in Malabar in the seventh century (More 2011), but a strong Muslim community only developed there in the twelfth century (Prange 2008; Shokoohy 2003; Dale 1980). By then, the political entity forged by the Cēra Perumāḷ of Makōtai ${ }^{1}$ had collapsed and was succeeded by numerous rival, petty kingdoms (Narayanan 2013). However, by the end of the fifteenth century, the Zamorins had emerged as the most powerful polity. Through military expeditions to the south of Calicut, they gained control of vast tracts of agricultural land and imposed influence over maritime trade. Consequently they laid claim to titles such as samudra rāja (King of the Ocean), which allegedly became Sämütiris in Malayalam and Zamorins in European usage, and kunnalakkōn (Lord of the Sea and Mountains). ${ }^{2}$

Under the Zamorins, Muslims enjoyed many commercial, political and religious privileges. In the early sixteenth century, Tomé Pires commented that "all the merchants and sailors of Malabar, who traded on the seas are Muslims" (Pires 1944). The Zamorins patronized Muslims to such an extent that in Europe, primarily among the Portuguese, they were known as "Moorish chieftains" (Narayanan 1972: 6). Again, writing around 1520, Duarte Barbosa (d. 1521), a Portuguese official stationed in Malabar, said:

$[\mathrm{M}]$ any of the gentiles turned Moors for any offence which they received amongst one another: and the Moors did them great honour, and if they were women they immediately married them. These people have many mosques in the country in

\footnotetext{
* I am much indebted to Ameet Parameswaran and Rachel Varghese (Jawaharlal Nehru University), Justin Mathew (Gottingen University), Abhilash Malayil (Indian Institute of Technology Mandi), Archa N. Girija (University of British Columbia), two anonymous reviewers and editors of JIOWS for their invaluable comments on earlier drafts of this article. 1. They also are known variously as Cēramān Perumāḷ, Kulasēkharas, and Second Cēras.

2. There are other theories about the origin of the name and its relation with oceanic trade, but none of those are conclusive (see Haridas 2016).
} 
which they also unite in council. [...] They are great merchants, and possess in this place wives and children, and ships for sailing to all parts with all kinds of goods. They have among them a Moorish governor who rules over and chastises them, without the king meddling with them. [...] These Moors were very well dressed and fitted out, and were luxurious in eating and sleeping. The king gave to each one a Nair to guard and serve him, ${ }^{3}$ a Chety scribe for his accounts, and to take care of his property, and a broker for his trade. To these three persons such a merchant would pay something for their maintenance, and all of them served very well (Barbosa 1866, 146-48).

Such prestigious royal receptions were given mainly to the paradēsi - or foreign Muslims. Yet, indigenous Muslims, known as Māppilas, who had converted to Islam or were raised as Muslim through being born to a local woman who had married a foreign Muslim, also enjoyed an elevated social status; many of them served in higher positions in the military, or as body-guards or assistants to the Zamorins (Bouchon 1987). Concerning the Māppiḷas, Barbosa wrote:

[...] there are a great quantity of Moors, who are of the same language and colour as the gentiles of the country. They go bare like the Nairs, only they wear, to distinguish themselves from the gentiles, small round caps on their heads and their beards fully grown. ${ }^{4}$ So that it appears to me that these people are a fifth part of all the inhabitants that there are in this country. They call these Moors Mapulers [Māppilas], they carry on nearly all the trade of the seaports: and in the interior of the country they are very well provided with estates and farms. So that if the King of Portugal had not discovered India this country would have had a Moorish king... (Barbosa 1866, 146).

For Malabar, a narrow stretch of land between the Arabian Sea to the west and the mountain ranges of the Western Ghats to the east, Indian Ocean trade was a major source of income. Consequently, maritime traders gained great political and social respect. In the fifteenth century, ifnot earlier, the Māppilas had an upper-hand in brokering regional spices and other goodsfromlocalproducerstotheArabtraderswhospecializedinlong-distancemaritimetrade.

The arrival of the Portuguese in the Indian Ocean threatened to undermine the

3. Nair is a caste group that predominantly held military occupations in the region.

4. The skull-cap was a religious marker that distinguished Muslims from the Hindus of Malabar. For example, the anonymous author of Kéralotpatti, possibly written in the seventeenth century, identifies a Muslim who fought against the Portuguese as "vatțattoppikkāran" or "the one with rounded cap" (Kêralōtpatti 1868, 95). However, as in Kéralōtpatti this Muslim is identified as a paradéśi captain, referred to as Arayil Kuriyan from Pāṇți (pāṇțiparadeśsi), Barbosa's observation that skull-caps were exclusively worn by the Māppilas is incorrect. 
status quo, for the Portuguese aimed to eradicate the Muslim mercantile community on the Malabar Coast and thus gain a monopoly of the spice trade. However, the Zamorin rejected Vasco da Gama's request in 1502 to banish all Muslims from his kingdom, stating that it was unthinkable "to expel more than 4,000 households of them who live in Calicut as natives, not as strangers, and from whom his kingdom had received much profit (Barros 1777; Pearson 1987, 73. Emphasis is mine). Subsequent animosity between the Zamorins and Portuguese lasted for about a century.

In this context, a number of Muslim intellectuals started writing treatises and delivering sermons to mobilize their community in support of the Zamorins. Others raised funds to finance, or even directly participate in, military engagements against the Portuguese (De Varthema 1863). The treatises containing strong jihadi sentiments invoke Islamic scriptures and classical Arabic texts that highlight certain theocratic-geographical

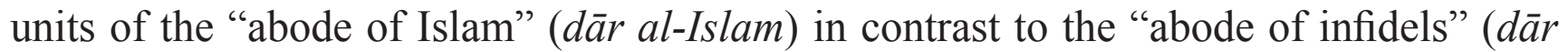
$a l$-harb). ${ }^{5}$ Strikingly, some extol the Hindu Zamorin as possessing the requisite moral, cultural and political qualities to reign, in contrast to Muslim sovereigns such as 'A $\overline{1}$ Rajas of Cannanore who, because of their alliance with the cross-worshipping Portuguese, were portrayed as corrupt and illegitimate rulers. At the same time, for reasons that I shall explain below, one author replaces the Zamorins with the 'Ádil Shahs of Bijapur Sultanate as his ideal kings. These diverse political imaginations of a minority community from the same socio-political and cultural context raise a number of questions. Did these traditional Muslim intellectuals imagine sacred geographical entities that coincided with or opposed the Zamorins' political boundaries? Did not such contrasting imaginaries endanger the existence of Muslims in such a remote place under a non-Muslim ruler? Was the image of a homeland ruled by the "infidel" Zamorins not a contradiction in terms? Before addressing these questions, let me briefly introduce the "jihadi" texts and their authors.

\section{Politics in Writing against Violence}

In sixteenth-century Malabar, numerous Arabic works were written by Muslim scholars, most of them graduates of Ponnāni Makhdūm College - the most famous Islamic educational centre in Malabar (Robinson 1984) — and/or of institutes in Mecca and Cairo, the educational heartlands of the Muslim world. Makhdūm College was a mosquecum-college that emerged from a small mosque established in the late fifteenth century by Ibrāhīm bin Zayn al-Dīn al-Makhdūm, who had migrated to Ponnāni from Cochin.

\footnotetext{
5. The prime motivation of these texts, often explicit in their titles, is to incite readers to engage in jihad (holy war against the enemies of Islam) or to celebrate victory in any such wars. As this impulse, along with their general style, is similar to other early Islamic texts written on or for jihad, I have categorized them here as jihadi texts. But we should bear in mind that jihad is not the only concern of these texts. For example, Tuhfat al-mujahidin that I discuss below in detail is one of the best early historical accounts on Malabar for it deals with many social, cultural and religious aspects of the region.
} 
Through his successors, the college eventually rose to prominence, and its educational legacy continues to be extolled by local Muslims who call it "Little Mecca" or the "Mecca of Southern India." Over the course of time, various students from Makhdūm Collegeproduced remarkable texts which have yet to be studied thoroughly. Suffice it to say that the authors of all texts discussed in this paper were linked to this college, either as teachers or students.

While most works written by our authors were theological, juridical, and spiritualistic in content, a few also directly addressed the issue of Portuguese aggression on the Malabar Coast. These "jihadi texts," in which the authors incite their readers against the Portuguese, have not hitherto been studied thoroughly, despite numerous works on the South-Asian jihad tradition (Hiro 2012; Jalal 2008; Akbar 2002). Exceptions include Engseng Ho (2009) who examined the renowned and frequently translated Tuhfat al-mujāhidīn (henceforth Tuhfa) by Zayn al-Dīn Junior (d. 1583?), who was born and brought up in Malabar and supposedly educated at Mecca under renowned scholars such as Shihāb al-Dīn bin Hajar al-Haytamī (d. 1566). Some historians have also examined another jihadi text, namely Fath al-mubin (hereafter Fath) by Muhammad al-Kālikūtī (d. 1616?) after its translation into English four decades ago (Khan 1975).

However, no scholar has yet examined other jihadi texts for their historical content. These include works such as Tahrị̄ ahl al-imān (henceforward Tahrị̄̂) written by Zayn al-Dīn Senior (1467-1522) sometime before the early 1520s (Kooria 2012), and Khuțat al-jihādiyya and Qașīdat al-jihādiyya (hereinafter Khuṭba and Qașīda respectively) written by al-Kālikūtī in around 1570 . These three texts provide a clear understanding of the perceptions and mentalities of Muslim intellectuals in Malabar during the period in which hostilities between the Zamorins and Portuguese intensified. I will not go into the details of the battles or the treaties between the Zamorins and Portuguese here, as these have been analysed by numerous other scholars. ${ }^{6}$ Instead, I explore how the Muslim intelligentsia perceived their own political existence under a non-Muslim ruler in a context where their religious identity and ancestral and geographical affiliations were under threat, and how, given the religio-geographical notions they held that divided territories between Islamic and non-Islamic realms, they understood this non-Muslim kingdom. Most Muslims in sixteenth-century Malabar, and these authors in particular, were of somewhat non-Malabari origin. Barbosa noted that the Muslim community in Calicut included Arabs, Persians, Khurasanis, and Deccanis (Barbosa 1866, 147). Zayn al-Dīn Senior and Junior, two of the authors of jihadi texts, belonged to a family that had migrated to Malabar from the Coromandel Coast, and claimed a lineage that went back to Abū Bakr (c.573-634), the Companion of the Prophet Muhammad. The fact that Muslims in Calicut professed a different faith than that of local rulers and

6. See, for example, the nationalistic historical writings of Panikkar 1929; Nambiar, 1963; compared with the studies of Pearson 1987, 1998; Subrahmanyam 1997, 2012; Malekandathil, 2001, 2013; and Mathew 1983, 2003. 
that most were of foreign origin and culture may not have initially mattered, but the situation changed significantly after the arrival of the Portuguese who questioned the "indigeneity" and thus rights of Muslims "from Cairo and the Red Sea" to live and trade in Malabar. The texts under my focus reveal how the Muslim scholars, who also mostly led and represented their community, responded vehemently to the Portuguese.

\section{Ambiguous Loyalty and the Abode of Islam}

Tahrie d, the first known work in the jihadi-genre of Malabar, was written in response to the early Portuguese presence in the Indian Ocean (Muhammad 1990). It is a short poetical work of 175 lines that primarily discusses the religious merits and obligations of engaging in holy war. In the text, the author seldom refers explicitly to distinctions between Muslims and non-Muslim kings or domains, but does criticise rulers in general for disregarding the wretched conditions of Malabari Muslims resulting from the Portuguese attacks. He also accuses some rulers of allying with the Portuguese at a time when Muslims most needed their support. He writes:

Fighting against them [the Portuguese] is incumbent on each Muslim

Who is healthy and equipped with provisions; [...]

For all our weakness and lack of provisions,

We fought against them in the best ways we could, for years.

Although some of our rulers were with them in this,

They could not gain victory which blots out disaster.

- (Tahrī 2012 , 52, 63; Emphasis is mine).

The author's attitude to the political stance of the Zamorin against the Portuguese is unclear, although he does criticize "some of our rulers" who have allied with the enemy. Identifying these rulers is difficult. They could have included kings from the Malabar Coast, such as the Rajas of Cochin or the 'Āli Rajas of Cannanore who, from the very beginning, supported the Portuguese in order to protect their social, political and economic interests from the mighty Zamorins (Malekandathil 2001). The 'Âli Rajas sent gifts to the King and Queen of Portugal, and asserted their autonomy on the northern Malabar Coast where, for over a century, their ports had welcomed Portuguese ships (More and More 2008). Hence, if the Tahrī d's "our" qualifies a geographical identity, it could refer to the Malabari rulers of Cochin and Cannanore. However, if "our" denotes a religious identity, it could mean Cannanore and other Muslim kingdoms in the western IOW. While plausible in the case of Cannanore, because of its geographical proximity, references to the wider Muslim world need clarification. Malabar Muslims were in constant touch with the Muslim kingdoms of Yemen, Egypt and Turkey, as is reflected in records of ambassadorial visits and in official correspondence (Lambourn 2008; 2011). 
Furthermore, the author of the Tahrị with the changing political structures and situations there through both his first-hand experiences and the maritime information networks that connected the Middle Eastern and South Asian coasts. Thus, he would have known if any Muslim ruler in the broader IOW had allied with the Portuguese, and thus be subject to criticism on religious grounds.

The religious affiliation of political institutions and a network based on religious identities seem to have been very important for the author who, later in Tahriẹ, offers prayers for the rulers/nobles ( $s \bar{a} d \bar{a} t)$ and promises godly rewards in return for their help in combatting the Portuguese:

Masters, in you we put our trust

With the grace of the Lord of the Throne, in all hardships.

We are thirsty and you are the clouds about to pour down;

I wish I knew whether it could quench our thirst.

If you could save us from the agony,

You will be rewarded in abundance.

The Lord has induced us to fight against the enemy,

Especially to fight to dissolve our sufferings

- (Tahrị̄ 2012, 52, 63-64).

In this passage, it is evident that the author views his audience within the context of a broader religious-political community with whom offers of godly rewards would resonate. In addition, the very fact that this work, like all other sixteenthcentury Malabari jihadi texts, is written in Arabic, indicates that the author wished it to be accessible to, and represent the views of, Muslims living in the wider IOW.

The Tahrị emphasises Malabar as an abode of Islam, regardless of who was the ruler or of their religious persuasion. The author underscores jihad as an obligation for all Muslims at this critical moment. Thus for him all sons and slaves, who according to the Islamic laws of war had to obtain the consent, respectively, of their parents and masters, in order to fight, had to join the battle even without such consent. The legal justification for this was that the Portuguese had "entered the abode of Muslim community" (dār li ummat Ahmad) ${ }^{7}$ andhadcapturedandincarcerated the followersofIslamic Sharia(Tahrị̄̂2012:52). ${ }^{8}$

This identification of Malabar as an abode of Muslims is very striking, as

7. This literarily means: the House $(d \bar{a} r)$ of Ahmad's community. Aḥmad is a common name used in the Islamic literature to denote Prophet Muhammad. The Arabic term $d \bar{a} r$ technically means "house", though it has generally been translated as "abode" in similar contexts.

8. In K.M. Mohamad's translation (2012: 63), dār li ummat Aḥmad has been simplistically translated as "houses of Muslims." These phrases do not do justice to the original Arabic phrases. 
the author was fully aware that non-Muslim Hindu Zamorins sat on the throne. It is rooted in the longer Islamic legal tradition of considering that the Muslim inhabitants of dār al-harb, or regions hostile to Islam, were subject to rulings different from those that governed the inhabitants of $d \bar{a} r$ al-Islam, or Islamic territories, when performing rituals, engaging in warfare, trading or migrating. This difference in the application of Islamic law evolved from developments in the Shāfi 'i School of Islamic law, originally established by Idrīs al-Shāfi '̄i (d. 820)(al-Sayyid 2002: 126; Weber, 2002: 147). It was to the Shāfi 'i School that the Tahrīẹ's author belonged.

For al-Shāfi $` \overline{1}$, faith and unbelief were the decisive elements to be considered when differentiating dār al-Islam from dār al-harb. Hence, faith-based identity played a crucial role in demarcating territories, recognising the political legitimacy of regimes, and differentiating allies from enemies. Adding to this binary division between Islamic and non-Islamic lands and rulers, al-Shāfi 'i created a third category, that of dār al-șulh/ 'ahd (Abode of Truce/Treaty) meaning non-Islamic countries that had concluded treaties with Muslim kingdoms (Bonner 2006: 92-93; Mottahedeh and al-Sayyid 2001: 28-9; Weber 2002: 137, 148). Later scholars added a further geographical category, dār alamān (Abode of Safety), referring to areas where Muslims were protected and free to practice their religion without hindrance. While the third category had the legal status of dār al-harb, the fourth was chiefly considered to be part of dār al-Islam. Since the Zamorins always provided security and protection for their Muslim subjects, Malabar fell under the category of $d \bar{a} r$ al-amān and thus was bound by the rulings of $d \bar{a} r a l-$ Islam. That was why the Tahrị d, whose author was well educated in Islamic law and theology, identified Malabar as an abode of Islam where war was obligatory should it be attacked by an infidel power that threatened the implementation of the Sharia. As such, the Tahrị $\underline{d}$ constitutes one of the earliest texts to identify an Indian Ocean region ruled by a non-Muslim ruler as dār al-Islam/al-amān. It also indicates the inclination of a Shāfi ' $\overline{1}$ scholar for the predominant Hanafi view that a territory ruled by a nonbeliever could form part of dār al-Islam provided that its ruler offered protection to his Muslim subjects and that a Muslim judge ( $q \bar{a} d \bar{l})$ had jurisdiction in Islamic affairs. This sixteenth-century work from Malabar can also be seen as a precedent for the debate that developed among eighteenth- and nineteenth-century north Indian Muslim scholars over whether India, under the British colonial rule, formed part of dār al-Islam or dār al-harb.

\section{Loyal Servant to the True Ruler}

Our second author, al-Kālikūtī, popularly known as Qāḍī Muhammad among the local Malabar Muslims because he composed the first extant Arabi-Malayalam text entitled, Muhy al-Dīn Māla, also wrote three jihadi works, including Khuṭba, Qașìda and Fath, all three produced in the context of the Zamorins' attempt to re-conquer and demolish the Portuguese fort in Cāliyam, to the south of Calicut. The Khutba 
was clearly composed before, and the other two texts after, the battle; the former is prose and the latter two are poems. In the Khutba, the author incites Muslims to participate in the war while the other works express the joys of victory. ${ }^{9}$ In the Khutba and Qașida, explicit references to the dichotomies of Islamic/non-Islamic terrains or rulers are rare. The Khutba emphasises the obligation, merits and rewards of war against the Portuguese who were attacking Muslim pilgrims, merchants, travellers, settlements, and establishments. Because it was composed as a sermon to be delivered at the congregational mosque of Cāliyam, it does not call for non-Muslims to fight. The Qașida addresses the legal and ethical issues facing Muslims in times of turmoil and war. It congratulates those who participated in the war for their illustrious victory. However, the author warns warriors not to engage in piracy and robbery, acts that God seeks to punish through banishment, amputation and execution:

The Scripture proposes four definite rules

To pirates, whom God named as

"Warring enemies of God, the guide"

And "spoilers of the earth":

First, deport them from the homeland,

If hazarded without murder and assault;

Second, amputate legs and arms,

If they robbed without murder;

Third, kill them without mercy,

If they killed without larceny;

Fourth, execute and crucify them,

If they committed both murder and burglary

— (Qașìda MSS, lines 22-27).

It is striking to note that this admonition of piracy came at a time when the Portuguese were complaining of piracy carried out by the Malabaris and especially the Māppila Muslims. As Michael Pearson and other scholars have pointed out, Portuguese sources referring to the Malabar Coast constantly talk about "corsairs" and "pirates" who, in Asian sources, are represented as brave warriors (Pearson 1979). This is not the case with the Qașìda, which makes a clear distinction between warriors and pirates and denounces any act of piracy at sea or robbery on land. It even states that, when drinking water was scarce, access to it should be given to animals rather than to pirates. However, the Qașida condemns looting of "Muslim" ships, voyagers

9. The author does not provide dates or other details concerning the composition of his works. 
and property, which again can be connected to the geographical identification in the Tahrī of Malabar as an abode of safety and hence, of Islam. In this sense, his call for the protection of Muslim ships should not be understood as a call for the protection of one community at the expense of another, either within or outside Malabar. The third work, a poem, emphasises Malabar as a land of Islam. Entitled Fath al-mubīn li muhibb al-muslimīn al-Sämirì șăhib Kälikūt ("The manifest victory to the Zamorin of Calicut, lover of Muslims"), it praises the Zamorins for the strong support they offered their Muslim subjects. The author al-Kālikūtì makes clear in the preface that the poem is about an unprecedented war in Malabar between the "Muslim-loving" Zamorin and the "infidel" Portuguese (al-faranjī). This delineation of two non-Muslim politicaleconomic entities into binaries of friend and foe intensifies as the poem progresses. Its author composed it in the hope that kings the world over, especially in Syria and Iraq, would learn of the bravery of the Zamorins and consequently be inspired to join the fight against the Portuguese. One stanza extols the heroism of the Zamorin: ${ }^{10}$

They ${ }^{11}$ may realize the courage of the Sultan Zamorin,

Who is well-known all throughout the world

Ruler of the famous Calicut; may it remain glorious.

Lover of our religion, Islam, and Muslims,

From among his subjects.

Helper of our religion, executor of Sharia,

Even on our sultan to do khutba. ${ }^{12}$

All the Muslims are his subjects

Wherever they stay in his domains

If an infidel oppresses a Muslim,

The Zamorin fights him on behalf of the Muslims

- (Fath 1975, 169, lines: 13-18). ${ }^{13}$

These lines demonstrate how deeply al-Kālikūtī respected the Zamorins. The following sections of the poem further elaborate on the honours and positions that Muslims in general and their leaders in particular enjoyed in the kingdom of Calicut. For this, al-Kālikūtì gives

10. Mu'id Khan, in his translation, does not divide the poem into stanzas. The manuscript I consulted is more organized and has multiple titled sections, the first of which, devoted to the Zamorin, is entitled: Bāb fì madh al-Sämirī wa fakhrih, or "Chapter on the Praises and Prides of the Zamorin".

11. Rulers everywhere, but especially in the Middle East.

12. Emphasis added. For an elaboration on this line, see below.

13. This translation, and also the ones below, is based on Mu'id Khan's translation, but with significant revisions. 
credit to the Zamorins. However, his frequent use of the word sultan call our attention. For example, he uses it to denote the Zamorin. This is revealing, especially since two lines before it is first mentioned, he uses generalized terms such as mālik, malik, and șāhib, to connote different royal persons. He also uses the term in a religious context, that of the khutba (Friday sermon - not be confused with the above-discussed jihadi-text Khutba - written with capital-letter K). Elizabeth Lambourn (2008, 2011) argues convincingly that Muslims in Malabar, and in the Indian subcontinent in general, attempted to connect themselves with Middle Eastern caliphates or other powerful Muslim entities by naming and praying for their sultans in the Friday sermons. Such a ritualistic association of naming and prayer that was authorised by the Zamorin meant much to devout Muslims like al-Kâlikūtī, even though it may not have signified much for the Zamorin, as in his kingdom the khutba was a minor religious ritual performed by a minority community.

Al-Kālikūtī's second reference to the word sultan is in a section describing the Zamorins'attempts to seek support from the Mamlūks and Ottomans to fight the Portuguese. This is interesting in the context of the historical use of the word sultan among the Sunni Muslims. From the beginning, the title sultan was used by the great Sunni rulers, and it eventually became synonymous with rulers who defended Sunnī Islam during the Crusades and promoted a simultaneous Islamic religious revival. When the Seljūqs, Mamlūks and Ottomans bore the title of sultan, it was with these connotations in mind. Its usage by the Ottomans following the fall of the Mamlūks became more significant in juxtaposition to the Șafawid Shī 'ì ruler who bore the title "shah" (Kramers and Bosworth). Al-Kālikūtī's usage of the term sultan thus demonstrates his admiration of the Zamorin as an ideal king who was the equal of, if not superior to, Muslim rulers. The poet clearly indicates that Muslim rulers in the Middle East and South Asia should be inspired by the virtuous Zamorins (see below). His realization that the Zamorins, but no Muslim ruler, supported the people of Malabar in the Cāliyam Battle indubitably motivated him to discard his earlier ambiguity (as expressed in the Khutba) and declare political allegiance to the Zamorins. Through the Fath, he declared this to his audience in both Malabar and the wider Islamic world.

According to al-Kālikūtī, the "cross-worshipping Portuguese infidels" were enemies of not only indigenous Malabari communities, but also of Islam and the Sharia. Therefore whoever formed an alliance with the Portuguese was sinful. In this context, Muslim sultanates of adjacent areas such as Cannanore, Bijapur and Ahmad Nagar (the 'Ālī Rajas, 'Ādil Shah dynasty and Nizāām Shah dynasty respectively) were apostate because their rulers had signed commercial treaties with the Portuguese. In the Fath, he calls upon the Muslim community to support the Zamorins through mass participation in jihad against the Portuguese and their Muslim allies. In this respect, the Fath treats the Zamorins as if they were Muslims, and by doing so, goes against the traditional restrictions in the Islamic laws of war which give authority to declare jihad only to a legitimate Muslim ruler wherein jihad is to be fought only against non-Muslims. The Fath, by contrast, portrays the Hindu Zamorins as equal to legitimate Muslim rulers, 
with authority to wage jihad against both the Portuguese and their Muslim allies. His characterisation of the Zamorins as equal to Muslims is a constant refrain. For example, he writes at the end of the first section:

Incumbent it is on all Muslims that such a one [i.e. the Zamorins] should be prayed for like the Muslim.

For, he is fighting against (infidels) in spite of his disbelief, while a Muslim king does not do so.

They are fighting for the sake of their own religion and for that of other Muslims, but they (Muslim rulers) make peace with the infidels.

- (Fath 1975, 170-171, lines: 50-52).

At the end of the poem, he again underscores his appreciation of the Zamorin whom he contrasts with the Muslim sultan of Bijapur Ali 'Ādil Shah who, according to alKālikūtī, betrayed Muslims and Islam through his collaborations with the Portuguese:

He made peace with the Franks, without there being any persistent need or pretext (for its justification). ${ }^{14}$

Thus, he violated his pact before Allah forgetting all about his letters and promises. [...]

O! Ye kings of Muslims! Take a lesson from one of the infidel kings. [...]

We have not seen any Muslim king paying attention, drawing sword against them.

In order to ward off these cursed infidels from the Muslims who are defenceless.

But, the Zamorin, in spite of his being a non-Muslim, fought against the Franks and expended all his treasures

— (Fath 1975, 182, lines: 503-504, 509, 513-515).

Evidently, al-Kālikūtī viewed theZamorins as more capablethan Muslimrulers of protecting the religious, social and military affairs of Malabari Muslims. As is reflected in his passage on the Battle of Câliyam, he glorifies the war efforts of the Zamorins, elevating them above any Muslim ruler in history: "Have you ever heard of such a war in the past either among the Arabs or Persians (Fath 1975, 182, line: 507)?" He states further that the Zamorin virtues he details "are but a tenth part of a tenth of a tenth of his merit" (Ibid, line: 519).

14. Ali 'Âdil Shah of Bijapur signed a treaty with the Portuguese on 13 December 1571. 


\section{A Disloyal SubJect?}

This alignment of interests between a Muslim scholar and his Hindu king had seemingly faded within a decade, by the time Zayn al-Dīn Junior dedicated Tuhfa to his ideal king, Sultan 'Ālì 'Ādil Shah of Bijapur (r. 1558-1579). In the preface, Zayn al-Dīn mentions that it was written

as an offering for the gracious acceptance of the most glorious of sultans, and the most beneficent of monarchs, who has made war against infidels the chief act of his life, having himself glorified God, and made his name to be upheld with reverence by all; having ever devoted himself to the service and protection of the servants of God (Tuhfa 1833, 9). ${ }^{15}$

In subsequent passages, the author further elaborates the qualities of 'A Ail Shah, describing him as a perfect ruler for Muslims. This raises a number of questions: why does Zayn alDīn Junior switch his political loyalty from the Zamorins, rulers of the country in which he lived, to a distant king? How could he have dedicated his work, which attacks the Portuguese, to a king whom the author of the Fath critiqued for having collaborated with the Portuguese? How could an ardent Sunnī scholar, propagating Shāfi '̄ism and Sufism on the Malabar Coast, have dedicated his work to 'Ālì 'Âdil Shah, an ardent Shī' $\overline{1}$ who abolished many Sunnī practices in his court and brought Shī 'îsm to its earlier glory in Bijapur? ${ }^{16}$ Is it an example of Islamic sectarian tolerance that existed among the Shî ${ }^{-} \overline{\text { is }}$ and Sunnīs in the sixteenth century, as Nainar claims in his translation (Tuhfa 2006, 99)?

First, I cannot help but notice a remarkable discrepancy both in the original text and the scholarly studies. The text specifies that the work is dedicated to "Sultan 'A $1 \overline{1}$ 'Ādil Shah" (Tuhfa 2006, 7) for whose long life, glory, political power, and promotion of religious revival, it prays. However, from other sources, we know that 'Āli 'A dil Shah was assassinated by a eunuch in 1579 . Thus, if the book was written in 1583 , as many scholars claim, up to which year its narrative extends, the author certainly would not have prayed for the long life of 'A $\bar{l} \overline{1}$ 'A $\overline{d i l}$ Shah who was by that time already dead. Then, why did he offer such a prayer? I presume that the author made a mistake, and must have meant Ibrāhīm 'Ādil Shah II (r. 1580-1627) instead of his predecessor, 'Ālì 'Ādil Shah.

15. I use Tuhfa's translations of Rowlandson (1833) and Nainar (2006) interchangeably, as I found particular passages from each of them to be more convincing once I cross checked with the original (1987).

16. The Bijapur rulers switched their allegiance between Sunn̄̄ and Shī' $\overline{1}$ traditions and whenever one followed a tradition contradicting his predecessor, he usually took strong measures to convert the court and the kingdom. 'A $\bar{l} 1 \overline{1}$ 'A dil Shah is known for his those actions following his conversion to the Shì ${ }^{-} \overline{1}$ tradition (Eaton 1978, 67-8). 
If that was the case, the descriptions in the Tuhfa's preface, dedication and prayer make perfect sense. Ibrāhīm II, enthroned at a very young age, was a passionate adherent of Sunnīsm, which he made the state religion, and remained a Hanafì despite attempts from his nobles to persuade him to embrace Shī īsm (Eaton 1978; Thomaz 2014, 21-22). It is against this backdrop that we should read the avowals of Tuhfa:, which suggest that Ibrāhīm II

is the reviver of the Faith, eradicating heresy and error from the territories of Allah ... is a great ruler, whom the days and nights have refined, notwithstanding his young age ...[and] endeavours to root out the heretics and to extirpate the wrong doers ...may Allah exalt and strengthen the foundation of Faith by means of his power (Tuhfa 2006, 6-7).

Therefore, the assumed problem of Sunnī-Shī 'issm, and related "exemplary attitude" of sectarian tolerance, are not evident. The same goes for the anti-Portuguese sentiment of the Bijapur Sultanate; while 'A $\bar{l} \overline{1}$ 'Âdil Shah alternated between enmity and friendship with the Portuguese, Ibrāhīm II was initially reluctant to forge any relationship with them, which nurtured Zayn al-Dīn's hope that the king might adopt an anti-Portuguese stance. However, Ibrāhīm II subsequently opened the doors of his kingdom to the Europeans, resulting in a "Golden Age for Portuguese-Bijapur relations"(Alam and Subrahmaniam 2012, 202), but by then Zayn al-Dīn's must have finished and dedicated his book.

Turning to the questions of why the author pledged allegiance to a distant king rather than to his own sovereign, and the role of religion in that decision, I refer to Lambourn's study of the khutba-networks (Lambourn 2008). The Malabari Muslim tradition of naming Muslim sultans, either from the northern parts of the Indian subcontinent or from the Middle East, dates back to the thirteenth or fourteenth centurys. It was an expression of a formalized "relationship of allegiance $\left(t \bar{a}^{\prime} a\right)$ between each Muslim community and a specific Islamic polity" through which Sunnī Muslim communities living outside the dār al-Islam connected themselves to the Islamic polities within the dār al-Islam. Such an allegiance did not signify rejection of the rulers under whom they lived. The same sentiment was expressed in the Tuhfa the author of which praises the Zamorins for measures they took to ensure freedom of religion for the Muslims:

Muslims throughout Malabar have no leader possessed of power to rule over them. Rather, their rulers are Hindus, who exercise judicial authority and organize their affairs by enforcing the payment of debts or fines if anyone is subjected to such payments... The rulers make it convenient for the Muslims to organize Friday congregation prayers and festivals like ' $\overline{\mathrm{I}}$. The stipend for the $m u$ 'ad $\underline{d}$ ins (callers to prayer) and the $q \bar{a} d \bar{l} \bar{s}$ (religious judges) are paid by the government. The government makes special arrangements for implementing among the Muslims their own Sharia. In greater part of Malabar, whoever 
neglects the Friday prayer is punished or fined (Tuhfa 2006: 45-46, with slight modifications). ${ }^{17}$

Also, the Tuhfa speaks highly of the Zamorins' efforts to protect the lives and wealth of Muslims in theirkingdom. Likethe Fath, italso criticises Muslim rulers and nobles for failing to take any interest in initiating jihad against the Portuguese, despite it being an obligation to do so given that the foreign unbelievers were invading "Muslim territories (Tuhfa 2006, 13)." Instead, it was the "Muslim-loving" Zamorins who invested in the battle to safeguard the lives and dignity of Muslims (ibid, 15). Furthermore, the Tuhfa contains many references to the generally benign attitude of the Zamorins towards Muslims, to the extent that, as was expressed in the Tahrị and Fath, Malabar could be considered to be an abode of Islam.

Why, then, did the author of Tuhfa dedicate his work to the Sultan of Bijapur? There were three potential reasons. First, such a dedication was similar to praying for (or naming) a Muslim sultan in the Friday sermons, through which Muslims from "peripheries" of Islamic world subjected themselves to a wider spiritualistic sovereignty that did not necessarily have any political connotations. Second, it was an attempt to make an anti-Portuguese alliance by calling on the Bijapur Sultan to support the Zamorins. Third, it was a work in which an ardent Sunnī author expressed religiously-motivated encouragement for the newly crowned Sunnī ruler in his stand against "heretical" ideas. Therefore, even though the political allegiance expressed in the Tuhfa might appear to contradict that of preceding texts, it actually does not stand against the Zamorins. Instead, it backed the anti-Portuguese networks and endeavours of the time, and - in common with the previous works discussed - considered the Zamorin Kingdom as part of the abode of Islam.

\section{Conclusion}

The sixteenth-century texts from Malabar discussed in this paper illuminate the perspectives of a minority Muslim intelligentsia living under "secular" dominions during a time of economic, political and religious conflict with the Portuguese and, by extension, with all Europeans. As such, the texts help us comprehend the diverse and complex dilemmas faced by Muslims who travelled to, or settled in, non-Muslim regions of the IOW. In the Iberian Peninsula following the Reconquista, Spanish Muslims (Moriscos or Mudéjars) were perceived as a politically disloyal fifth-column (Valensi 2013; Soyer 2013). However, the texts presented here demonstrate that in sixteenth-century Malabar, the Muslim minorities maintained allegiance to local, non-Muslim rulers who valued their loyalty. As such, these texts merit further scholarly attention, as does the relationship

17. Also see Tuhfa 2006, 15 for a similar statement by the author. 
between similar religious minorities in other regions of the IOW threatened by the arrival of Europeans. 


\section{Works Cited}

\section{Analysed Texts}

Fath al-mubīn of Muhammad al-Kālikūtī: Khan, M.A. Muid. 1975. "Indo-Portuguese

Struggle for Maritime Supremacy (as Gleaned from an Unpublished Arabic Urjuza:

Fathul Mubiyn)." In Studies in the Foreign Relations of India (from Earliest

Times to 1947): Prof. H.K. Sherwani Felicitation Volume, ed. P.M. Joshi and M.A.

Nayeem, 165-83. Hyderabad: State Archives, Government of Andhra Pradesh.

Khutbat al-jihādiyyat of Muhammad al-Kālikūtī, Manuscript at the private collection of

Pāññil Aḥmad Kuț̣i Musliyār and Kutub Khāna of Aḥmad Kōya Shāliyātī.

Qașìdat al-jihādiyyat of Muhammad al-Kālikūtī, Manuscript at the private collection of Pāññil Aḥmad Kuțtị Musliyār and Kutub Khāna of Aḥmad Kōya Shāliyātī.

Tahrị̄ ahl al-imān of Shaykh Zayn al-Dīn Sr., trans. and ed. K.M. Muḥammad. Calicut: Other Books.

Tuhfat al-mujāhidīn fì ba 'ḍ akhbār al-Burtughālīyīn of Shaykh Zayn al-Dīn Jr. 1987. Tripoli: Kullīyat al-Da 'wat al-Islāmīyat, (trans. Michael John Rowlandson. 1833. London: Oriental Translation Fund of Great Britain and Ireland); (trans. S. Muhammad Husayn Nainar. 2006. Calicut: Other Books).

\section{Other Primary Sources}

Barbosa, Duarte. 1866. A Description of the Coasts of East Africa and Malabar: In the Beginning of the Sixteenth Century. trans. Henry E.J. Stanley. London: The Hakluyt Society.

Friedmann, Yohanan. 1975. "Qișșat Shakrawartī Farmāḍ: A Tradition Concerning the Introduction of Islam to Malabar." Israel Oriental Studies 5: 233-258.

Keralolpatti: The Origin of Malabar. 1868. Manglore: Basel Mission Press.

Pires, Tomé. 1944. The Suma Oriental of Tomé Pires: An Account of the East, from the Red Sea to Japan, Written in Malacca and in India 1512-1515. London: Hakluyt Society. 
Varthema, Lodovico de. 1863. The Travels of Ludovico di Varthema in Egypt, Syria, Arabia Deserta and Arabia Felix, in Persia, India, and Ethiopia, A.D. 1503 to 1508. London: Hakluyt Society.

\section{SECONDARY Sources}

Akbar, M.J. 2002. The Shade of Swords: Jihad and the Conflict between Islam and Christianity. London: Routledge.

Alam, Muzaffar and Sanjay Subrahmanyam. 2012. Writing the Mughal World: Studies on Culture and Politics. New York: Columbia University Press.

Bonner, Michael David. 2006. Jihad in Islamic History: Doctrines and Practice. Princeton: Princeton University Press.

Bouchon, Genevieve. 1987. "Sixteenth Century Malabar and the Indian Ocean." In India and the Indian Ocean, 1500-1800, ed. Ashin Das Gupta and M. N. Pearson, 162-184. Calcutta: Oxford University Press.

Curtin, Philip D. 1984. Cross-cultural Trade in World History. Cambridge and New York: Cambridge University Press.

Dale, Stephen F. 1980. Islamic Society on the South Asian Frontier: The Māppilas of Malabar, 1498-1922. Oxford: Clarendon Press.

Eaton, Richard Maxwell. 1978. Sufis of Bijapur, 1300-1700: Social Roles of Sufis in Medieval India. Princeton: Princeton University Press.

Haridas, V.V. 2016. Zamorins and the Political Culture of Medieval Kerala. New Delhi: Orient BlackSwan.

Hiro, Dilip. 2012. Apocalyptic Realm: Jihadists in South Asia. New Haven: Yale University Press.

Ho, Engseng. 2009. "Custom and Conversion in Malabar: Zayn Al-Din Al-Malibari's Gift of the Mujahidin." In Islam in South Asia in Practice, ed. Barbara Daly Metcalf, 403-08. Princeton: Princeton University Press.

Jalal, Ayesha. 2008. Partisans of Allah: Jihad in South Asia. Cambridge, MA: Harvard University Press. 
Kooria, Mahmood. 2012. "Taḥrị Ahl al-Imān: An Account from Malabar against the Early Modern European Interventions in the Indian Ocean World." In Taḥrị̣ Ahl al-Iman, trans. and ed. K.M. Muhammad, 19-48. Calicut: Other Books.

Kramers, J.H. and Bosworth, C.E. "Sultān.” In Encyclopaedia of Islam, Second Edition, ed. P. Bearman, Th. Bianquis, C.E. Bosworth, E. van Donzel, W.P. Heinrichs. Consulted online on 06 March 2017.

Lambourn, Elizabeth. 2008. "India from Aden: Khuṭba and Muslim Urban Networks in Late Thirteenth-Century India." In Secondary Cities and Urban Networking in the Indian Ocean Realm, C. 1400-1800, ed. Kenneth R. Hall, 55-97. London: Lexington Books.

2011. "Khutba and Muslim Networks in the Indian Ocean (Part II) - Timurid and Ottoman Engagements." In The Growth of Non-Western Cities: Primary and Secondary Urban Networking, ed. Kenneth R. Hall, 131-58. London: Lexington Books.

Malekandathil, Pius. 2013. The Mughals, the Portuguese, and the Indian Ocean: Changing Imageries of Maritime India. New Delhi: Primus Books.

- 2001. Portuguese Cochin and the Maritime Trade of India, 1500-1663. New Delhi: Manohar.

Mathew, K.S. 2003. Maritime Malabar and the Europeans, 1500-1962. Gurgaon: Hope India Publications; London: Greenwich Millennium.

- 1983. Portuguese Trade with India in the Sixteenth Century. New Delhi: Manohar.

More, J.B.P. 2011. Origin and Early History of the Muslims of Keralam, 700 A.D.-1600 A.D. Calicut: Other Books.

and Leena More. 2008. "The Rise and Fall of the Port of Cannanore: Aspects of Trade and Politics in Malabar between the Sixteenth and Seventeenth Centuries." In The Indian Trade at the Asian Frontier, ed. S. Jeyaseela Stephen, 103-16. New Delhi: Gyan Publishing House. 
Mottahedeh, Roy and Ridwan al-Sayyid. 2001. "The Idea of Jihad in Islam before the Crusades." In The Crusades from the Perspective of Byzantium and the Muslim World, eds. Angeliki E.L. and Roy Mottahedeh, 23-29. Washington, D.C.: Dumbarton Oaks Research Library and Collection.

Muhammad, K.M. 1990. "A Critical Study of Tahrid Ahl Al-Iman Ala Jihadi Abdat AlSulban." Islamic Culture 64: 121-30.

Nambiar, O.K. 1963. The Kunjalis, Admirals of Calicut. New York: Asia Publishing House.

Narayanan, M.G.S. 1972. Cultural Symbiosis in Kerala. Trivandrum: Kerala Historical Society.

. 2013. Perumāls of Kerala: Brahmin Oligarchy and Ritual Monarchy, Political and Social conditions of Kerala under the Cêra Perumāls of Makōtai (c. AD 800$A D$ 1124). Thrissur: Cosmo Books.

Panikkar, K.M. 1929. Malabar and the Portuguese: Being a History of the Relations of the Portuguese with Malabar from 1500 to 1663. Bombay: D.B. Taraporevala Sons and Co.

Pearson, M.N. 1979. "Corruption and Corsairs in Sixteenth-century Western India: A Functional Analysis." In The Age of Partnership: Europeans in Asia before Dominion, ed. M.N. Pearson and Blair B. Kling, 15-41. Honolulu: University Press of Hawaii.

1987. The Portuguese in India. Cambridge and New York: Cambridge University Press.

1998. Port Cities and Intruders the Swahili Coast, India, and Portugal in the Early Modern Era. Baltimore: Johns Hopkins University Press.

Prange, Sebastian. 2008. "The Social and Economic Organization of Muslim Trading Communities on the Malabar Coast." Ph.D. Dissertation: University of London.

Shokoohy, Mehrdad. 2003. Muslim Architecture of South India: The Sultanate of Ma'bar and the Traditions of the Maritime Settlers on the Malabar and Coromandel Coasts (Tamil Nadu, Kerala and Goa). London and New York: Routledge Curzon. 
109 An Abode of Islam Under a Hindu King: Circuitous Imagination of Kingdoms among Muslims of Sixteenth-Century Malabar

Soyer, Franois. 2013. "Faith, Culture and Fear: Comparing Islamophobia in Early Modern Spain and Twenty-First-Century Europe." Ethnic and Racial Studies 36, (3): 399-416.

Subrahmanyam, Sanjay. 1997. The Career and Legend of Vasco Da Gama. Cambridge and New York: Cambridge University Press.

- 2012. The Portuguese Empire in Asia, 1500-1700: A Political and Economic History. Chichester: John Wiley \& Sons.

Thomaz, L.F.F.R. 2014. "Iranian Diaspora and the Deccan Sultanates in India: A Study of Sixteenth Century Portuguese Sources." Studies in History 30 (1): 1-42.

Valensi, Lucette. 2013. Stranieri Familiari: Musulmani in Europa (Xvi-Xviii Secolo). Torino: Einaudi.

Weber, Edgard. 2002. « La Codification Juridique Du Jihad. » In Religion between Violence and Reconciliation, ed. Thomas Scheffler, 135-63. Wurzburg: Ergon Verlag. 